\title{
Studies on HIV integrase-LEDGF/p75 interaction inhibitory activity of isatine derivative using the alpha screen luminescent proximity assay
}

Periyasamy Selvam

From First International Science Symposium on HIV and Infectious Diseases (HIV SCIENCE 2012)

Chennai, India. 20-22 January 2012

\section{Background}

During the early stage of HIV-1 replication, integrase (IN) plays important roles at several steps, including reverse transcription, viral DNA nuclear import, targeting viral DNA to host chromatin and integration. Previous studies have demonstrated that HIV-1 IN interacts with a cellular lens epithelium-derived growth factor (LEDGF/p75) and that this viral/cellular interaction plays an important role for tethering HIV-1 preintegration complexes (PICs) to transcriptionally active units of host chromatin. Small molecule inhibitors of HIV IN/ LEDGF have emerged as promising new class of antiviral agents for the treatment of HIV/AIDS. Present work is to study the small molecule inhibitor of HIV IN/LEDGF.

\section{Method}

Isatine-sulphadimidine derivative (SPIII-5H) selected for these studies. HIV IN/LEDGF interaction inhibition assay performed by ALPHA screen technique, HIV integrase assay investigated by oligonucleotide based assay and molecular modeling studies also carried by using computational methods.

\section{Results}

Lead molecule SPIII-5H inhibits HIV IN/LEDGF interaction (protein-protein interaction) at $10 \mathrm{uM}$ and HIV integrase activity at $6.8 \mathrm{uM}$. From molecular modeling study indicates that SPIII-5H bind with active site of HIV integrase (DDE), change the conformation and interrupt the binding of HIV integrase with LEDGF.

Correspondence: selvaamin@yahoo.co.in

Devaki Amma Memorial College of Pharmacy, Chelembra, Malapuram673634, Kerala, India

\section{Conclusion}

SPIII-5H novel class of inhibitors of HIV IN/LEDGF interaction and this lead molecule is suitable for further molecular modifications.

Published: 4 May 2012

doi:10.1186/1471-2334-12-S1-05

Cite this article as: Selvam: Studies on HIV integrase-LEDGF/p75 interaction inhibitory activity of isatine derivative using the alpha screen luminescent proximity assay. BMC Infectious Diseases 201212 (Suppl 1):05.
Submit your next manuscript to BioMed Central and take full advantage of:

- Convenient online submission

- Thorough peer review

- No space constraints or color figure charges

- Immediate publication on acceptance

- Inclusion in PubMed, CAS, Scopus and Google Scholar

- Research which is freely available for redistribution
C Biomed Central 